\title{
PARENTAL INVOLVEMENT ON CHILD'S EDUCATION AT HOME DURING SCHOOL LOCKDOWN
}

\author{
Lim Seong Pek ${ }^{\left.a^{*}\right)}$, Rita Wong Mee Mee ${ }^{a)}$ \\ a) Universiti Selangor, Selangor, Malaysia \\ ${ }^{*}$ Corresponding Author: limsp@unisel.edu.my
}

Article history: received 10 July 2020; revised 19 August 2020; accepted 20 September 2020

\begin{abstract}
The pandemic of Covid-19 has changed how education works in the current time. A child's learning development has always been placed on the responsibility of the school. However, during the pandemic, parental involvement has become vital in the world of education. The involvement of just a few parents may influence the quality of instruction in a classroom or at home and, thereby, influence the academic development of many children in Malaysia. This research aims to determine parental involvement child's education in Selangor, Malaysia. Besides, it was also to help teachers and administrators to provide activities that encourage parents to participate in their child's school activities at home. The data was collected via questionnaires and phone interviews. The participants involved were 10 parents and 5 teachers from a local primary school at the selected area during Movement Control Order (MCO). Based on the finding of this research, parental involvement has had a big influence in their child's academic achievement. Although the importance of parental involvement is widely acknowledged in the educational society, most of parents showed that many parents still do not get involve effectively in their child's education whether in school or at home. In conclusion, parental involvement is very essential in primary education and this will help to enhance child's social relationships and promote a sense of self-esteem and self-efficacy
\end{abstract}

Keywords: parental involvement; academic achievement; self-esteem; self-efficacy

\section{INTRODUCTION}

Parent involvement in a child's education is consistently found to be positively associated with a child's academic performance and success in education [1] Precisely, children whose parents are more involved in their education have higher levels of academic performance than children whose parents are involved to a lesser degree. The influence of parent involvement on academic success has not only been noted among researchers, but also among policy makers who have integrated efforts aimed at increasing parent involvement into broader educational policy initiatives. Therefore, it is important to examine factors and barriers that hinder academic success and that are agreeable to change [2].

Parental involvement in the form of fostering interest and support has a major influence on learners' educational outcomes or achievement [3]. The school also plays an important role in determining the levels of parental involvement on children's education. Specifically, schools can outline their expectations of parents and regularly communicate with parents about what children are learning [1]. Also, schools can provide opportunities for parents to talk with school personnel about parents' role in their child's education through home visits, family nights, and wellplanned parent-teacher conferences. Then, when parents talk to their child about education, expect them to do well, make sure that out-of-school activities are constructive, and help them plan for college besides, make sure that their children perform better in school.
However, many parents feel uninformed about current educational practices and how they can be more involved with their child's learning. Most of them do not know their child's achievement in school. Sometimes, parents did not even give encouragement to their child as they were busy working but they expected their child to do well in education. As a result, their child felt demotivated and they did not perform well in their study due to the lack of attention and encouragement from their parents. Some of them felt forced to study and they could not perform well in their education. The overall belief that all parents matter really supports and encourages parents' participation in school activities and therefore, promotes learners' academic success [4].

There were little researches about the important instruments through which parental involvement influences children's academic performance in education. The present study thus required to extend the literature by examining potential pathways from parental involvement on children's achievement at early age. Research findings suggested that parents' attitudes, together with their behaviour and activities with regard to their children's education, have an effect on academic achievement [5]. Parental involvement in schooling is a powerful force, and that parents are a child's first and most enduring educator, and their influence cannot be overestimated [6].

The study specifically intended to establish the relationship between parental involvement and learners' performance in education. Parents have the distinct advantage over anyone else in that they can provide a more stable and continuously positive influence that could 
enhance and complement what the school fosters on their children. In this regard, parental involvement is undeniably critical [6]. However, with regard to the content of what children learn, many fall short because in general they do not possess the necessary education and therefore find it difficult to determine and understand what was done at school [4].

The basic motivation behind parents getting engaged in their child's education is on academic success [7]. Parents who believe in the importance of their child's education tend to be involved in educational activities, whereas parents who believe that teachers are the only ones responsible for the educational process are likely to be less involved. Trust between teacher-parent helps to increase the commitment to partnerships between teachers and parents [8]. When communication between parents and teacher occurs frequently, it helps to develop trusting and responsible relationships between them [7]. Educated parents are more likely to be involved in their child's educational activities at home.

\section{RESEARCH METHODS}

The purpose of this study was to determine parents' involvement in their child's education at home during the pandemic of Covid-19. Besides, it also helped teachers and school administration to provide activities for home-based learning that increased parents' participation in their child's education. This study was conducted using mixed method design which involved qualitative and quantitative data obtained from parents through questionnaire and in-depth interview. A qualitative study is an inquiry process of understanding a social or human problem, based on building a complex, holistic picture, formed with words, reporting detailed views of informants, and conducted in a natural setting [9].

The respondents for this study were parents and teachers of learners in a local primary school in Selangor, Malaysia. There were ten parents and five teachers participated as respondents. The type of sampling applied in this study was stratified purposeful sampling which involved a combination of sampling strategies such that subgroups were chosen based on specified criteria, and a sample of cases was then selected within these strata [9]. The study was carried out to obtained the information from parents from a wider cross section within year group and not just from one level. This would therefore provide a rich thick data necessary to make meaning of the phenomenon from the perspective of these parents.

\section{RESULTS AND DISCUSSION}

\section{A. Parents' Questionnaire}

The parents' questionnaire consists of 30 questions which was categorised into three categories. There were home-based involvement, school-based involvement and home-school conferencing. The questionnaire was distributed to 10 parents. The findings were presented as follow.
Table 1 shows responses on School-Based Involvement. Based on this figure, it shows that parental involvement in school seems encouraging yet improvement are needed. Question A1 states if parents volunteered in their child's homework. Among 10 respondents, three participants answered Always, five participants answered Sometimes and two participants answered Never. While Question A2 states if parents participated in parent-teacher activities. The result shows, two participants answered Always, seven participants answered Sometimes and a participant answered Never. Question A3 states whether parents participated in planning classroom activities with the teacher. Four participants answered Always, and six participants answered Sometimes.

Table 1. School-Based Involvement

\begin{tabular}{|c|c|c|c|}
\hline A. School-Based Involvement & ALIWAYS & SOMETIMIES & NEVER \\
\hline 1. I volunteer in my child's homework & 3 & 5 & 2 \\
\hline $\begin{array}{l}\text { 2. I participate in parent and family social } \\
\text { activities with the teacher }\end{array}$ & 2 & 7 & 1 \\
\hline $\begin{array}{l}\text { 3. I participate in planning classroom } \\
\text { activities with the teacher }\end{array}$ & 4 & 6 & 0 \\
\hline 4. I go on class trips with my child & 7 & 3 & 0 \\
\hline $\begin{array}{l}\text { 5. I talk with other parents about school } \\
\text { meeting and events }\end{array}$ & 4 & 3 & 3 \\
\hline $\begin{array}{l}\text { 6. I participate in planning school trips for } \\
\text { my child }\end{array}$ & 6 & 4 & 0 \\
\hline $\begin{array}{l}\text { 7. I meet with other parents from my child's } \\
\text { class outside of school }\end{array}$ & 7 & 3 & 0 \\
\hline $\begin{array}{l}\text { 8. I hear teacher tell my child how much } \\
\text { they love learning }\end{array}$ & 3 & 5 & 2 \\
\hline $\begin{array}{l}\text { 9. I participate in fund raising activities in } \\
\text { my child's school }\end{array}$ & 4 & 6 & 0 \\
\hline $\begin{array}{l}\text { 10. I feel that parents in my child's classtoom } \\
\text { support each other }\end{array}$ & 2 & 6 & 2 \\
\hline
\end{tabular}

Question A4 states whether parents went on class trip with children. Seven respondents answered Always while three respondents answered Sometimes. On the other hand, Question A5 states if parents spoke to other parents about school meeting and event. Four participants have answered Always, three participants answered Sometimes and three participants answered Never. Question A6 states if parents participated in planning class trips for children. Six parents answered Always and four parents answered Sometimes. Question A7 states whether parents met other parents outside of school. There were seven participants answered Always and three participants answered Sometimes.

Question A8 states if parents had heard teacher telling about their child loving to learn. Three respondents answered Always, five respondents answered Sometimes and two participants answered Never. As for Question A9, parents were asked if they participated in fundraising activities in child's school. Four participants answered Always and six participants answered Sometimes. Question A10, states whether parents felt other parents support each other in child's classroom. Two participants answered Always, six answered Sometimes and another two participants answered Never.

Table 2 shows responses on Home-Based Involvement. Question B1 states if parents spent time working with children on reading/writing skills. Four respondents answered Always and six respondents answered Sometimes. Question B2, respondents were asked whether they spent time with children working on creative activities. 
A respondent answered Always, five answered Sometimes, and four respondents answered Never. Question B3 states parents shared stories with their child about when they were in school. Two of participants have answered Always, five participants answered Sometimes and another three respondents answered Never. Question B4 states if participants shared stories about their study years. A respondent answered Always, six respondents answered Sometimes and three respondents answered Never.

Table 2. Home-Based Involvement

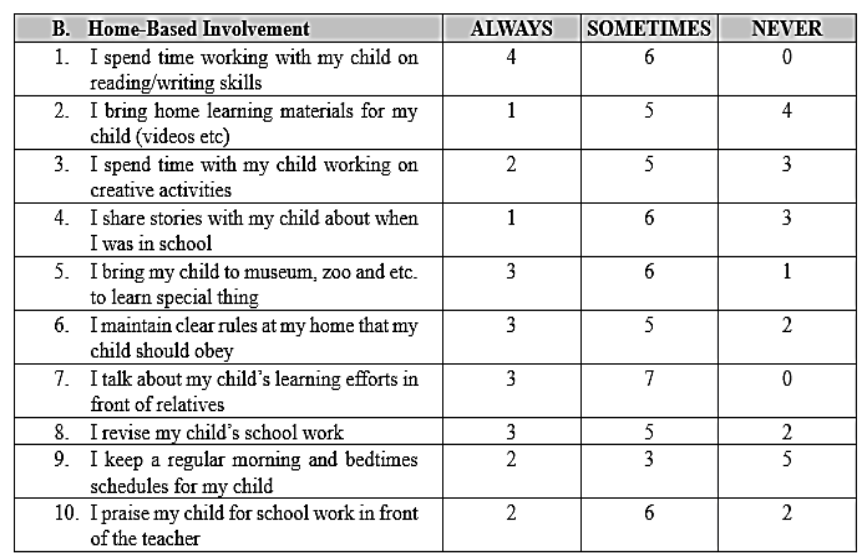

Question B5 states if participants brought their children to museum, zoo or others to learn special things. Three respondents answered Always, six answered Sometimes and a participant answered Never. Question B6 states if participant maintained clear rules at home that children should obey. Three of participants answered Always, five participants answered Sometimes while two participants answered Never. Question B7 states whether parents talked about their child's learning effort in front of their relatives. Three respondents answered Always while the other seven respondents answered Sometimes.

Question B8, participants were asked if they revised their child's school work. Three participants answered Always, five answered Sometimes and two answered Never. Question B9 states if participants kept regular morning and bedtimes schedules for children. Two participants answered Always, three participants answered Sometimes and five answered Never. Question B10 states whether participants praised their child for school work in front of the teacher. Two participants answered Always, six participants answered Sometimes and two participants answered Never.

Table 3 shows responses on Home-School Conferencing. Question C1 states whether parents talked to teacher about their child's progress with classmate at school. Three participants answered Always, three participants answered Sometimes and four participants answered Never. Question C2 states if participants talked to teacher about classroom rules. Three participants answered Always, four answered Sometimes and three answered Never. Question C3 states whether participants talked to teacher about children difficulties at school. Two of participants have answered
Always, six participants answered Sometimes and two participants answered Never.

Question C4 states if participants talked to teacher about school work to practice at home. Three of participants answered Always, four participants answered Sometimes and the other three participants answered Never. Question C5 states if participants talked to teacher about their child's accomplishments. A participant answered Always, seven answered Sometimes and two participants answered Never. Question C6 states whether participants talked to teacher about their child's daily routine. Two participants answered Always, four participants answered Sometimes and four participants answered Never.

\section{Table 3. Home-School Conferencing}

\begin{tabular}{|c|c|c|c|}
\hline C. Home-School Conferencing & ALWAYS & SOMETIMES & NEVER \\
\hline $\begin{array}{l}\text { 1. I talk to the teacher about how my child } \\
\text { gets along with his/her classmates at } \\
\text { school }\end{array}$ & 3 & 3 & 4 \\
\hline $\begin{array}{l}\text { 2. I talk with my child's teacher about } \\
\text { classroom rules }\end{array}$ & 3 & 4 & 3 \\
\hline $\begin{array}{l}\text { 3. I talk to my child's teacher about his/her } \\
\text { difficulties at school }\end{array}$ & 2 & 6 & 2 \\
\hline $\begin{array}{l}\text { 4. I talk with my child's teacher about } \\
\text { school work to practice at home }\end{array}$ & 3 & 4 & 3 \\
\hline $\begin{array}{l}\text { 5. I talk to my child's teacher about my } \\
\text { child's accomplishments }\end{array}$ & 1 & 7 & 2 \\
\hline $\begin{array}{l}\text { 6. I talk to my child's teacher about his/her } \\
\text { daily routine }\end{array}$ & 2 & 4 & 4 \\
\hline $\begin{array}{l}\text { 7. I attend conferences with the teacher to } \\
\text { talk about my child's learning or } \\
\text { behavior }\end{array}$ & 2 & 5 & 3 \\
\hline $\begin{array}{l}\text { 8. I schedule meetings with administration } \\
\text { to talk about problems or to gain } \\
\text { information }\end{array}$ & 0 & 1 & 9 \\
\hline $\begin{array}{l}\text { 9. I talk with my child's teacher to gain } \\
\text { information }\end{array}$ & 2 & 4 & 4 \\
\hline $\begin{array}{l}\text { 10. I talk with my child's teacher on the } \\
\text { telephone }\end{array}$ & 0 & 5 & 5 \\
\hline
\end{tabular}

Question C7 states if parents attended conferences with the teacher to talk about child's learning or behaviour. Two parents answered Always, five parents answered Sometimes and three parents answered Never. Question C8 states if participants ever scheduled meetings with administration to talk about problems or to gain information. A parent answered Sometimes and nine parents answered Never. Question C9 states if participants talked to child's teacher to gain information. Two participants answered Always, four answered Sometimes and four answered Never. Question C10 states if participants talked to their child's teacher on telephone. Five parents answered Sometimes and another five parents answered Never.

\section{B. Teacher's Questionnaire}

The teacher's questionnaire consists of 10 questions and was distributed to five teachers to be answered. Question 1 asked about year of teaching experience that they had. Two teachers answered less than a year. Six other teachers responded that they had one to five years of teaching experience and two teachers answered more than five years. Question 2 asked on how teacher communicated with learners' parents. Two teachers answered that they communicated with parents using social media, while a teacher used text messages and phone call. Another teacher 
interacted face-to-face and a teacher interacted with parents during child drop off and pick up from school.

Question 3 asked on what type of parental involvement that teacher expects from parents. Three respondents answered spending time in helping children's homework while two respondents expected to hold open communication in involvement of their child's education. Question 4 asked on what kind of activities teacher provided parents to get them to get involve in their child's education. Two teachers answered in-class and out-class activities while the other three teachers answered volunteering activities. Question 5 asked about activities preferred by parents. Three teachers responded for both in-class and outof-class activities and volunteering. A teacher responded to have family communication activities. While another did not answer.

Question 6 asked on what type of communication the teacher preferred with parents. Four teachers answered that they preferred face-to-face while a teacher preferred both social media, text messages and phone calls. Question 7 asked if teacher provides educational meeting to explain the benefits of parental involvement for parent. Three teachers answered Yes and two respondents answered No. Question 8 was an open ended question. It asked on what was teacher's perception towards parental involvement in their child's education. All teachers agreed that parental involvement is the most important for children. Most of the teacher answered that parental involvement nowadays had increased compared to ten years back. Teacher C stated, "I see that most of the parents nowadays do involve in their child's education".

Question 9 asked teachers whether they have ever encountered any problem with parents regarding their child's behaviour in school. Two answered that they had argued with parents about their child when their child was punished for not doing homework. Teacher E answered, "Sometimes what kids tell their parents about teacher punishing them in school was exaggerated till these parents thought that we had beaten their child. Usually I punish them by asking them to write out their mistake a piece of paper, but they, however, told their parents differently. So, parents misunderstood".

Question 10 involved teacher's opinion if parental involvement in education have had impact on children education. Most of teachers agreed that parental involvement does have positive impact in their child's education. Teacher $\mathrm{B}$ answered, "Parental involvements have the biggest impact in child's education since their parents' attention motivates their child to achieve better in education".

\section{Parent's Interview}

Question 1 asked what parents' perception is towards parental involvement in child's education. Three parents said that parental involvement is, indeed, the most crucial part in helping their child to have good performance in education. One parent has pointed that "I think parental involvement in children's education is very important since children need support and motivation for better achievement in education".
Half of the parents answered that they were involved in their child's school activities such as meeting. But, two parents had pointed out that sometimes they did not have time to get involve in their child's school activities since they were busy with their work, "I do not always have time to attend school activities or events because I am very busy with my work. It is not that I do not want to attend, but the time does not allow".

The next question asked parents' opinion about the effect of parental involvement in child's education. Parents in this study showed that parental involvement does give positive impact on children's achievement in education. Then, one parent said that, "Our child always needs their parents' support in order to enhance their achievement in education and have better motivation towards education". It means that, some parents do realize how important parental involvement in their child's academic achievement.

The following question asked parents' opinion about challenges in educating their child. Most of the parents responded to this question by saying that nowadays, there are a lot of challenges in educating children growing up in modern world compared to few years back. One mother pointed, "It is not easy to educate children nowadays because their environment is different compared to ten years ago". Another mother pointed out, "I need to be more assertive to my child since he likes to watch cartoon more than doing his homework".

Results from this study could be concluded that there are still lacks parental involvement in children's education especially in Home-Based Involvement and Home-School Conferencing. Not all parents were involved in their child's education whether at home or school. They were only few of parents that always involve in their child's education but not in all aspect. Besides, some of them rarely take part in their child's education and some of them did not even involve in their child's education whether in school or at home. During the interview, there were few parents stated that they were busy with their work and did not have time to get involved in their child's education. However, working is not an excuse for not to get involve in children's education as parental involvement in children's education does motivate children to perform better in their education.

\section{CONCLUSION}

Teachers in this study indicated a strong desire for parental involvement while parents do not indicate a desire for better communication with teacher or involve in children's education. Furthermore, teachers need to provide activities that will encourage parents to get involve in children's education especially at home and provide feedback to parents after they have participated in activities. Giving positive feedback increases parental involvement based in social exchange theory [8]. The theory stated that development of relationships based on interest exchange and how people respond to others' actions. Mutual exchange of benefits is an important element within the interaction process. Its mean that, when teachers provide feedback to 
parents, they feel appreciated for teachers' effort and their involvement means a lot more to teachers, school and children.

Results show that teachers fancy of having an open communication with parents rather than other ways of communication. The importance of communication is to step towards better parental involvement for parents, teachers and administrators to work together on operative communication [10]. Some parents in this study indicated interest in taking part in some school activities. Two parents mentioned that they did not participate in the school activities due to busy working schedule and it was not that they do not want to participate. Teachers need to be aware about parent-child relationship about involvement in education. So that they could plan a better way on how to encourage parents to participate in school activities. Most schools have parental involvement programmes that are not effective for several reasons such as parents' difficulty communicating in English or meeting hour that could not meet parents' schedules. Teachers need to create parental involvement programmes that include schools, families and the society to help in improving the educational process [3].

\section{REFERENCES}

[1] Durisic, M \& Bunijevac, M. 2017. Parental Involvement as an Important Factor for Successful Education. CEPS Journal, 7(3), 137-153.

[2] Williams, T. T., \& Sanchez, B. 2011. Identifying and Decreasing Barriers to Parent Involvement for InnerCity Parents. Youth \& Society, 45(1), 54-74.

[3] Lara, L. \& Saracostti, M. 2019. Effect of Parental Involvement on Children's Academic Achievement in Chile. Front. Psychol. 10, 1464.

[4] Afolabi, O. E. 2014. Parents' Involvement in Inclusive Education: An Empirical Test for the Psycho-Educational Development of Learners with Special Education Needs (SENs). International Journal of Educational Administration and Policy Studies, 6(10), 196-208.

[5] Guðlaug, G. 2010. Effects of Parental Involvement in Education: A Case Study in Namibia. Unpublished PhD dissertation Faculty of Education Studies, University of Iceland.

[6] Hornby, G. \& Lafaele, R. 2011. Barriers to Parental Involvement in Education: An Explanatory Model, Educational Review, 63(1), 37-52.

[7] Cankar, F., Deutsch, T., \& Syntonic, S. 2012. Approaches to Building Teacher-Parent Cooperation. CEPS Journal, 2(1), 35-55.

[8] Mahmood, S. 2013. First-Year Preschool and Kindergarten Teachers: Challenges of Working with Parents. School Community Journal, 23(2), 55-86.

[9] Creswell, J. W. 2014. Research Design: Qualitative, Quantitative and Mixed Methods Approaches (4th ed.), Thousand Oaks, CA: Sage.

[10] Kocyigita, S. 2015. Family Involvement in Preschool Education: Rationale, Problems and Solutions for the
Participants. Educational Sciences: Theory \& Practice, 15(1), 1-17. 